\title{
Does the Ingestion of Isoxaflutole Herbicide Affect the Midgut and Salivary Glands of Pentatomidae Predators? ${ }^{1}$
}

\author{
A Ingestão do Herbicida Isoxaflutole Afeta o Intestino Médio e Glândulas Salivares de \\ Predadores Pentatomidae?
}
GONÇALVES, T.S. ${ }^{2}$, SOARES, M.A. ${ }^{2}$, SANTOS, C.A. ${ }^{2}$, SANTOS, D.A. ${ }^{2}$, SANTOS, J.B. ${ }^{2}$, and BARROSO, G.A. ${ }^{2}$

\begin{abstract}
Podisus nigrispinus is a generalist predator naturally occurring in agricultural and forestry systems that effectively contributes to the population balance of phytophagous insects, especially defoliating caterpillars. Histological changes were evaluated in the salivary glands and midgut of $P$. nigrispinus caused by ingestion of systemic herbicide isoxaflutole. These predator females were fed with leaves of eucalyptus plants, Tenebrio molitor pupae or water, contaminated or not by herbicide. Salivary glands and midguts were dissected, processed and analyzed under a light microscope. Activity level and cell morphology of the salivary glands and midgut showed differences among insects fed on plants, contaminated water or pupae. The epithelia of the salivary gland and midgut of individuals which had no contact with the herbicide showed homogeneous cytoplasm, nucleus with predominance of decondensed chromatin and evident nucleoli, intense cell activity features. As for the insects in contact with contaminated food, they presented undeveloped nucleus and condensed chromatin. The luminal contents of the salivary glands in the contaminated insects had become more acidophilus than in insects without poisoning, as well as having heterogeneous and granular secretion, being more evident in the bioassay in which the insects fed on contaminated water. There was a marked morphological change in the midgut cells in contaminated insects. High degree of apoptosis, disorganization and secretory vacuoles in the epithelial cytoplasm were observed. The apical portion of the midgut cells proved undeveloped, irregular and partially destroyed. It is concluded that isoxaflutole causes morphological changes in the digestive system of the predator P. nigrispinus.
\end{abstract}

Keywords: biological control, cell apoptosis, digestive system, morphological change, Podisus nigrispinus.

RESUMO - Podisus nigrispinus é um predador generalista de ocorrência natural em sistemas agricolas e florestais que contribui de forma efetiva para o equilíbrio populacional dos insetos fitófagos, principalmente lagartas desfolhadoras. Avaliaram-se alterações histológicas nas glândulas salivares e no intestino médio de $\boldsymbol{P}$. nigrispinus causadas após ingestão do herbicida sistêmico isoxaflutole. Fêmeas desse predador foram alimentadas com folhas de plantas de eucalipto, pupas de Tenebrio molitor ou água, contaminados ou não pelo herbicida. As glândulas salivares e o intestino médio foram dissecados, processados e analisados em microscópio de luz. O nivel de atividade e a morfologia celular das glândulas salivares e do intestino médio apresentaram diferenças conforme a alimentação. Os epitélios da glândula salivar e do intestino médio de indivíduos que não tiveram contato com o herbicida apresentaram o citoplasma homogêneo, núcleos com predomínio de cromatina descondensada e nucléolos evidentes. Já os insetos que tiveram contato com o herbicida apresentaram o núcleo pouco desenvolvido e cromatina condensada, evidenciando baixa atividade metabólica. Os insetos contaminados apresentaram conteúdo luminal das glândulas salivares mais acidófilo que aqueles sem intoxicação, além de possuírem secreção heterogênea e granular, sendo mais evidente no bioensaio em que os insetos se alimentaram de água contaminada. Ocorreram mudanças morfológicas marcantes nas células do mesêntero nos insetos contaminados. Foram observados alto grau de

Recebido para publicação em 17.7.2015 e aprovado em 26.8.2015.

Universidade Federal dos Vales do Jequitinhonha e Mucuri, UFVJM, Diamantina-MG, Brasil.<marcusasoares@yahoo.com.br>.

Planta Daninha, Viçosa-MG, v. 34, n. 1, p. 125-132, 2016 
apoptose, desorganização e vacúolos secretores no citoplasma epitelial. A porção apical das células do mesêntero mostrou-se pouco desenvolvida, irregular e parcialmente destruida. Conclui-se que o isoxaflutole provoca alterações morfológicas no sistema digestório do predador $\boldsymbol{P}$. nigrispinus.

Palavras-chave: apoptose celular, alteração morfológica, controle biológico, Podisus nigrispinus, sistema digestório.

\section{INTRODUCTION}

Podisus spp. genus is important biological control agents in Brazil due to their natural occurrence and mainly their aggression and voraciousness. Predator Podisus nigrispinus Dallas, 1851 (Hemiptera: Pentatomidae) is a generalist; it feeds primarily on immature insects of various species of pests belonging to orders Lepidoptera and Coleoptera (Soto et al., 2012; Menezes et al., 2014; Reis et al., 2014).

These insects begin the digestion process by injecting saliva in the prey before eating it - a process known as extraoral digestion. Digestive enzymes are injected to liquefy the prey and facilitate the absorption of nutrients from him. This allows feeding on preys of the same size or larger than their own bodies. However, this behavior may be associated with high energy costs for the synthesis of enzymes in large quantities (Martinez et al., 2014).

Toxins and digestive enzymes of extraoral digestion can be produced by specialized structures such as salivary and maxillary glands, or in the intestine itself. Substances found in the salivary glands can be used to characterize the eating habits of insects. Predators need to obtain water in large quantities, often from plants, especially for the production of saliva used in extraoral digestion of feeding on preys (Martínez et al., 2014; Zanuncio et al., 2014). Thus, phytophagy as nutritional supplementation is an important feature of generalist predators and gives support to extraoral digestion.

Insects' midgut is involved with digestion and absorption of nutrients, and production of enzymes. This portion of the intestine of a zoophytophagous Hemiptera is divided into an enlarged foregut, a tubular midgut and a hindgut that is also dilated. The foregut is involved with the transport of ions and water, maintaining the electrolyte balance, besides digestion of carbohydrates, and is a major site for lipid storage. The process of digestion and enzyme secretion is observed over the midgut and hindgut (Fialho et al., 2013).

The insects' midgut is characterized as an organ with a large interface and is relatively unprotected between the insect's body from the inside and the environment. This encourages further studies on the digestion process and its interference or contamination. Thus, knowledge of the digestive process and its functions is important for the development of new control methods that are compatible with biological control (Terra \& Ferreira, 2005).

The use of herbicides for weed control in eucalyptus plantations can influence the abundance and composition of arthropod predators in agroecosystems and can cause their mortality or physiological and morphological impacts (Camilo et al., 2012; Menezes et al., 2012a). Predators may be exposed to herbicides by direct contact with the spray droplet or by eating prey and sap from contaminated plants, which reflects in the loss of feed quality, weight gain, developmental duration, survival, production and deposition of eggs, as well as predatory capacity (Cloyd \& Bethke, 2011).

Lack of knowledge of isoxaflutole herbicide digestion process, which is systemic, affects the forecast of morphological and histological changes in predators and their impact on the ecology and behavior of insects. In this context, the objective of this study was to verify the effects of this herbicide, used in eucalyptus cultivation, on the midgut and salivary glands of $P$. nigrispinus.

\section{MATERIAL AND METHODS}

Females of $P$. nigrispinus were obtained from rearing at the Insect Biological Control Laboratory of the Federal University of Vales do Jequitinhonha and Mucuri, in the Brazilian city of Diamantina, Minas Gerais, where such 
predator was bred at $25 \pm 2{ }^{\circ} \mathrm{C}, 70 \pm 10 \%$ of relative humidity and photophase of 12 hours and fed on pupae of Tenebrio molitor (Linnaeus) (Coleoptera: Tenebrionidae) ad libitum (Torres et al., 2009), bread in the same laboratory. Females were individualized with less than 24 hours of age and sexed according to the morphological characteristics of the abdomen.

A solution containing isoxaflutole at the concentration of $0.64 \mathrm{~g} \mathrm{~L}^{-1}$ of commercial product Fordor ${ }^{\circledR}$ was prepared, containing $750 \mathrm{~g} \mathrm{~kg}^{-1}$ of a technical product. A micro spray was used to spread the diluted pre-dose equivalent to $75 \mathrm{~g} \mathrm{ha}^{-1}$ of isoxaflutole. The spray distance was measured, and the contents were sprinkled and weighed on a precision scale of $0.1 \mathrm{mg}$ after application of the herbicide on a permeable paper surface $(0.210 \times 0.297 \mathrm{~m})$. The herbicidal mass deposited on the paper surface was $0.47 \mathrm{mg}$.

Three bioassays were conducted, in which leaves of Eucalyptus sp., pupae of T. molitor or distilled water, contaminated or not with the herbicide, were offered to predator $P$. nigrispinus. The sampling unit consisted of one female, arranged in a $500 \mathrm{~mL}$ plastic pot, with five repetitions.

Leaves of Eucalyptus sp. and pupae of T. molitor were previously sprayed with the herbicide solution or distilled water (control). The leaves had the petiole involved with wet cotton and were offered two hours after the treatment to avoid contamination by contact.

In the third bioassay, contaminated water was used with the herbicide at a concentration of $0.64 \mathrm{~g} \mathrm{~L}^{-1}$ or distilled water as a control. Both were offered in dental anesthetic tubes covered with a cotton wad.

After feeding, the insects were cryoanesthetized at $-18{ }^{\circ} \mathrm{C}$ for five minutes and dissected, removing the midgut and the thorax portion where the salivary glands are located. The procedure was performed with tweezers and fine-tipped scissors in physiological saline solution, and the histological parts were transferred to fixative Bouin solution. After 24 hours, the parts were placed in tap water for 30 minutes and then in 50\% alcohol for 24 hours to remove excess fixative. Subsequently, histological specimens were stored in $70 \%$ ethanol.
To make the slides, the parts were dehydrated in an ascending alcohol series $(70$, $80,90,95$ and $100 \%)$; later they received three baths of xylene $(100 \%)$ and were embedded in paraffin. Histological sections of $5 \mu \mathrm{m}$ were made in a Lupetec MRP09 microtome, which were stained with hematoxylin and eosin. The slides were examined under Primo Star Zeiss photomicroscope and photographed with a Axioncam ERc5s camera attached to it. Data were subjected to descriptive analyses.

\section{RESULTS AND DISCUSSION}

$P$. nigrispinus individuals fed plants, pupae or water contaminated with isoxaflutole herbicide showed low salivary gland secretory epithelia, with little developed and condensed chromatin nucleus (Figures 1B, C, D), evidencing low protein synthesis activity. As for those which did not receive contaminated food, they exhibited the secretory cells nuclei of the major salivary glands with a predominance of decondensed chromatin (Figure 1A). Nuclei with decondensed chromatin show DNA with more surface for transcription, indicating an increase in protein synthesis (Li et al., 2007). This suggests that the metabolic activity of the major salivary glands secretory cells was higher in the $P$. nigrispinus samples that were given food without contamination.

The appearance of the $P$. nigrispinus' major salivary glands luminal contents differs between insects fed plants, pupae and water contaminated with isoxaflutole herbicide and those without contamination; secretion in the latter's glands presented a homogeneous aspect of their contents (Figure 1A), with the presence of a few granulocytes. As for those receiving the contaminated food, they had very heterogeneous secretion and basophil granulocytes (Figure 1D).

In Hemiptera (suborder Heteroptera), the salivary glands play a digestive function, because they have aqueous fluids with an acidic pH of $6.0 \pm 0.09$ (Fialho et al., 2013). However, it was noted that the luminal contents in the contaminated insects was found more alkaline due to the predominance of the blue color in the slides, conferred by hematoxylin (primary stain). This was most 


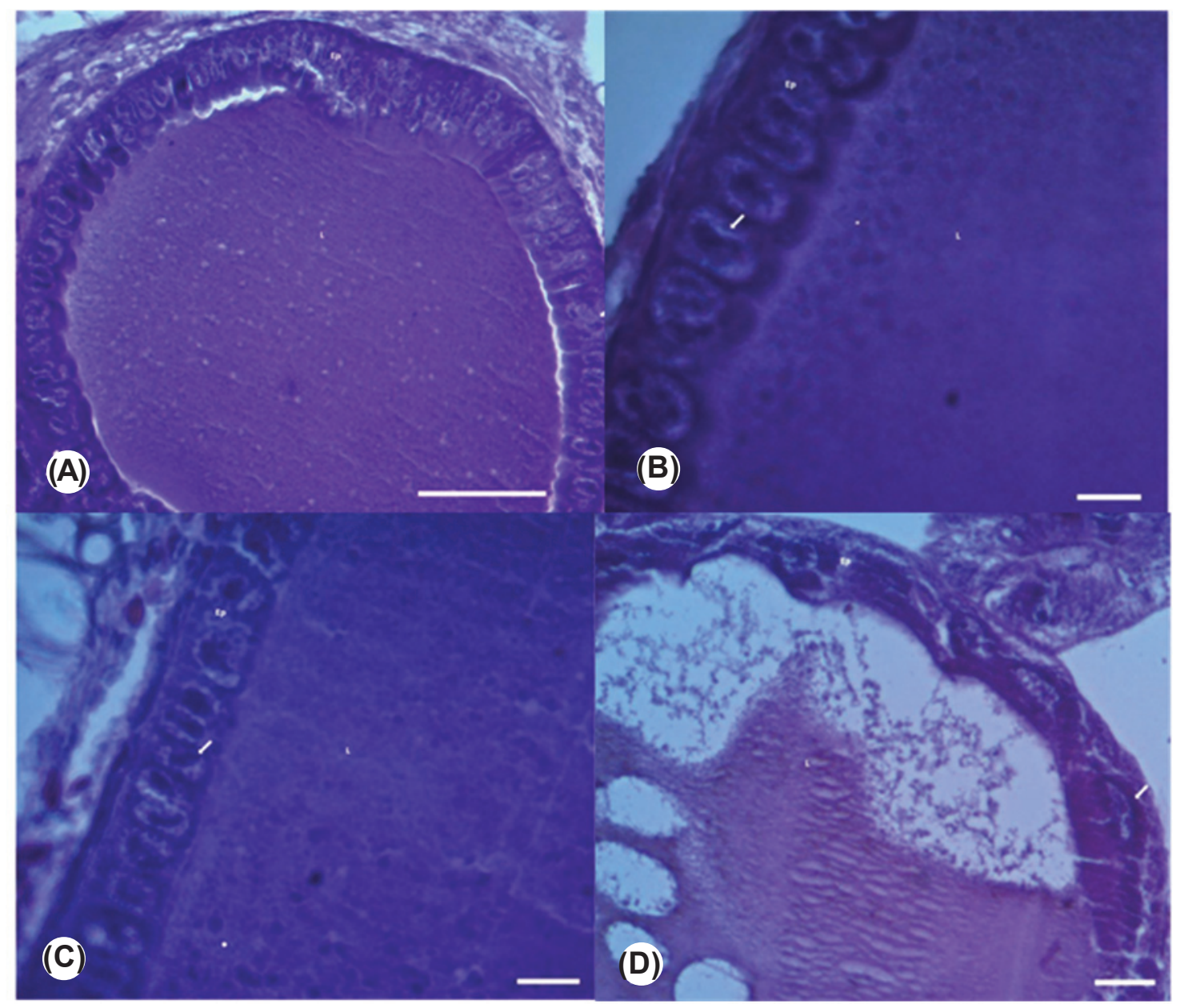

A. Salivary gland of insects fed pupae sprayed with distilled water (control) showing lumen (L), epithelium (Ep), and nucleus (arrow). Bar $=50 \mu \mathrm{m}$. B. Salivary gland of insects fed pupae sprayed with herbicide, showing lumen (L), epithelium (Ep), nucleus (arrow), and the granular area (*). Bar $=10 \mu \mathrm{m}$. C. Salivary gland of insects fed on plants sprayed with herbicide showing lumen (L), epithelium (Ep), nucleus (arrow), and the granular area $\left(^{*}\right)$. Bar $=10 \mu \mathrm{m}$. D. Salivary gland of insects fed with a commercial herbicide solution, showing lumen (L), epithelium (Ep), and nucleus (arrow). Bar $=10 \mu \mathrm{m}$.

Figure 1 - Optical microscopy of the salivary gland of Podisus nigrispinus (Heteroptera: Pentatomidae).

evident in the bioassay in which the insect was fed with contaminated water (Figure 1D).

The enzyme composition of the insects' saliva is not constant because it changes, depending on the individuals' feeding or age (Torres \& Boyd 2009). Differences in the composition of secretions produced by salivary glands have been reported for Notocnecta glauca (Heteroptera: Notonectidae), Naucoris cimicoides (Heteroptera: Naucoridae), Nepa cinerea (Heteroptera: Nepidae), Gerris lacustris (Heteroptera: Gerridae), Pentatoma rufipes (Heteroptera: Pentatomidae) (Baptist, 1941), Oncopeltus fasciatus (Heteroptera: Lygaeidae)
(Miles, 1967), Lethocerus uhleri and Belostoma lutarium (Heteroptera: Belostomatidae) (Swart et al., 2006) and Brontocoris tabidus (Heteroptera: Pentatomidae) (Azevedo et al., 2007). These studies indicate that salivary glands may play different roles in insects, being involved in digestion, paralysis of preys and lubricating the mouthparts, and that the type of feeding can influence the performance of these activities.

The midgut of $P$. nigrispinus has a similar pattern to that of other insects. It consists basically of an epithelium surrounded by a basement membrane and with two muscular 
layers: longitudinal and circular. The midgut can be further divided anatomically into three parts: a dilated foregut, a tubular and long midgut, and a hindgut, again dilated, located near the insertion of the Malpighian tubules system (Fialho et al., 2013).

The $P$. nigrispinus' midgut wall is formed by a single layer of columnar cells, and the lumen is coated by a thin perimicrovillar membrane, as observed in B. tabidus (Fialho et al., 2009). The morphology of columnar cells varies with the species, feeding status and the midgut area. These cells have microvilli, which are surrounded by an extracellular membrane, the perimicrovillar membrane, which is important in the digestion of proteins, compartmentalization of digestive processes and absorption of dilute amino acids (Azevedo et al., 2009). This intestinal area appears to be the main site of nutrients absorption in Heteroptera predators (Fialho et al., 2009).

Podisus nigrispinus fed plants, pupae and water without contamination have shown a homogeneous cytoplasm, nuclei with predominance of decondensed chromatin and evident nucleoli (Figure 2A) showing intense protein synthesis characteristics. The apical area has shown no obvious changes and presented fewer vesicles than in the insects that received food contaminated with the herbicide.

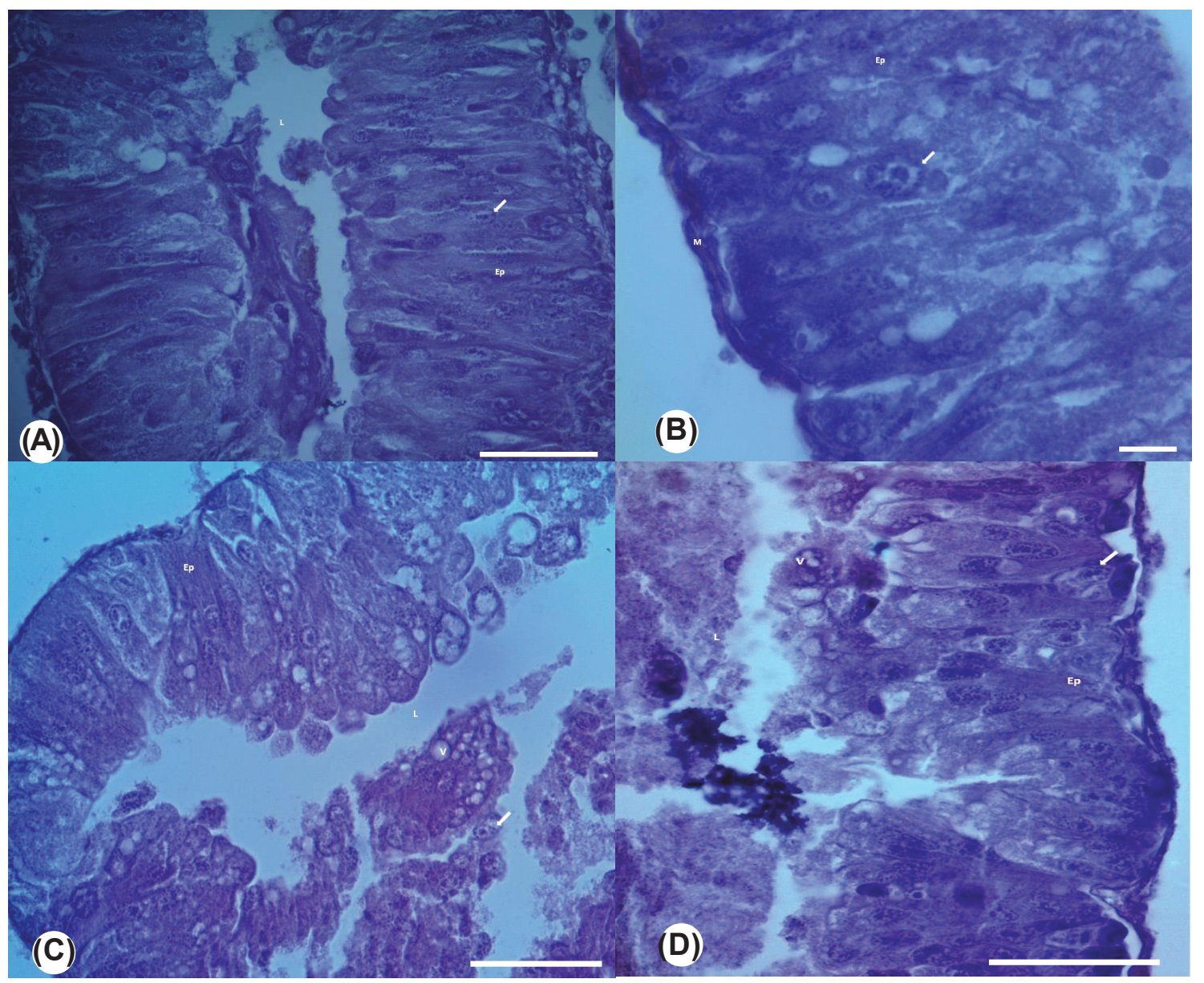

A. Midgut of insects fed with distilled water (control) showing the lumen (L), epithelium (Ep), and nucleus (arrow). Bar $=50 \mu \mathrm{m}$. B. Midgut of insects fed with a commercial herbicide solution, showing epithelium (Ep), nucleus (arrow), and muscles (M). Bar $=10 \mu \mathrm{m}$. C. Midgut of insects fed pupae sprayed with herbicide, showing lumen (L), epithelium (Ep) nucleus (arrow), and vesicles (V). Bar $=50 \mu \mathrm{m}$. D. Midgut of insects fed on plants sprayed with herbicide, showing lumen (L), epithelium (Ep), nucleus (arrow), and vesicles (V). Bar $=50 \mu \mathrm{m}$.

Figure 2 - Optical microscopy of the midgut of Podisus nigrispinus (Hemiptera: Pentatomidae). 
Apoptosis, or a genetically directed process of cell self-destruction, is an essential process to maintain the development of living beings, and it is important to eliminate unnecessary or defective cells (Gonçalves et al., 2013). Insects that had contact with food contaminated with the herbicide showed large morphological changes in the midgut cells, with high levels of apoptosis and evident cellular disorganization (Figures 2B, C, D). The nucleus presented condensed chromatin and evident nucleolus. In addition, there was the presence of numerous secretory vesicles of varying sizes in the epithelial cytoplasm, located in the cell apical area, where the cytoplasmic content is projected to the outside (Figures 2C, D). The area where the microvilli of the apical portion are found has performed poorly developed, irregular and partially destroyed (Figure 2C). These effects would be a result of cell intoxication, whose signals were similar to those observed in the digestive system of Aedes aegypti (Diptera: Culicidae) in contact with tannins of Magonia pubescens (Sapindaceae) (Valotto et al., 2011).

Several factors can be pointed out as the cause of cell toxicity in $P$. nigrispinus after eating isoxaflutole. High dosages applied in the field, amount and type of active ingredient present, salts and adjuvants of the formulation and synergistic effects of the product mixture could be cited as cytotoxic factors for insects and inherent to herbicides (Menezes et al., 2012b; Leite et al., 2015). Herbicide molecules could still affect the insects' physiology, causing oxidative stress by acting as strong reducing agents. These molecules can react with molecular oxygen to produce superoxide anion in arthropods, as reported for herbicide paraquat (Krucek et al., 2015), and may cause cell damage and induce apoptosis. However, in general, the mechanisms and physiological paths by which herbicides can poison natural enemies are still not fully understood.

The midgut cells in all bioassays in which the insect came into contact with the herbicide showed up shapeless and with an appearance of degeneration, indicative of apoptotic cells (Figures 2C, D). Stimuli such as infections, mutations, viruses, toxic assaults, heat shock, low amount of nutrients, ionizing radiation, etc. have been described as triggering this cell death process (Gonçalves et al., 2013).

The apoptosis of epithelial cells in the midgut ensures the removal of metals and toxic substances ingested by insects (Rost-Roszkowska et al., 2008), besides eliminating cells infected by pathogens. During apoptosis, the cell undergoes characteristic morphological changes, such as shrinkage, loss of adhesion to the extracellular matrix and to neighboring cells, chromatin condensation and formation of apoptotic bodies (Gonçalves et al., 2013). Apoptosis is carried out in animal cells by a family of proteases, the caspases, produced in the form of inactive precursors called pro-caspases, that are activated by proteolytic cleavage in response to signals which induce cell death. Activated caspases cleave and activate other family members, resulting in a proteolytic cascade, and also cleave other important cellular proteins, such as those which form the nuclear lamina. Apoptosis is dependent on caspase activation, which occurs by two different pathways: extrinsic, mediated by membrane receptors, and intrinsic, mediated by mitochondria (Daniel et al., 2014).

In insects, apoptosis is related to tissue reorganization that occurs during metamorphosis or natural involution of an organ in adulthood. Cell death has also been linked to environmental stressors such as insecticides or herbicides (Daniel et al., 2014). Chromatin compaction in the periphery of the nucleus or in one or more scattered plots is one of the earliest cellular changes that occur during apoptosis. Vesicles comprise part of the cytoplasm or whole organelles during autophagy. This process is considered important in the renewal of cellular organelles in conditions of lack of nutrients, or even as a cell death mechanism (Denton et al., 2012; Tognon et al., 2013). The large presence of vesicles comprising various parts of the cells suggests the non-viability of these ones by the herbicide (Figures 2C, D).

While apoptosis is important for the survival of multicellular organisms because it eliminates damaged or infected cells which can interfere with the body's normal function, in excess it may impair the overall functioning of tissues (Portt et al., 2011; Clapp 
et al., 2012), damaging important processes in digestion and, consequently, $P$. nigrispinus' role of predation and survival.

The activity level and cell morphology of the salivary glands and midgut showed differences among insects that received food contaminated or not. The luminal contents of the main salivary gland of $P$. nigrispinus individuals varied with intoxication by the herbicide, from acidic to basic. These differences may represent chemical changes in secretions. The evaluation of the biochemical aspects of these compounds is needed to understand the changes caused by the insect intoxication status. The midgut, too, has changed with the poisoning because its cells with the arrival of contaminated food, changing its morphology and leading to cell apoptosis.

\section{ACKNOWLEDGMENT}

We thank CNPq [Conselho Nacional de Desenvolvimento Científico e Tecnológico (National Counsel of Technological and Scientific Development)], CAPES [Coordenação de Aperfeiçoamento de Pessoal de Nivel Superior (Coordination of Improvement of Higher Education Personnel)], and FAPEMIG [Fundação de Amparo à Pesquisa do Estado de Minas Gerais (Research Support Foundation of the Brazilian State of Minas Gerais)].

\section{LITERATURE CITED}

AZEVEDO, D. O. et al. Notes on midgut ultrastructure of Cimex hemipterus (Hemiptera: Cimicidae). J. Med. Entomol., v. 46, n. 3, p. 435-441, 2009.

AZEVEDO, D. O. et al. Biochemical and morphological aspects of salivary glands of the predator Brontocoris tabidus (Heteroptera: Pentatomidae). Braz. Arch. Biol. Technol., v. 50, n. 3, p. 469-477, 2007.

BAPTIST, B. A. The morphology and physiology of the salivary glands of Hemiptera-Heteroptera. Quart. J. Microsc. Sci., v. 83, n. 329, p. 91-139, 1941.

CAMILO, S. S. et al. Impactos toxicológicos de herbicidas recomendados para a cultura do milho em ninfas do predador Podisus nigrispinus (Hemiptera: Pentatomidae). R. Bras. Herb., v. 11, n. 3, p. 339-346, 2012.

CLAPP, C. et al. Untangling the roles of anti-apoptosis in regulating programmed cell death using humanized yeast cells. Front. Oncol., v. 2, n. 1, p. 59-69, 2012.
CLOYD, R. A.; BETHKE, J. A. Impacto of neonicotinoid insecticides on natural enemies in greenhouse and interior scape environments. Pest Manag. Sci., v. 67, n. 1, p. 3-9, 2011.

DANIEL, A. G.; PETERSON, E. J.; FARRELL, D. R. N. P. The bioinorganic chemistry of apoptosis: potential inhibitory zinc binding sites in caspase-3. Angew. Chem., v. 126, n. 16, p. 4182, 2014.

DENTON, D.; NICOLSON, S.; KUMAR, S. Cell death by autophagy: facts and apparent artefact's. Cell Death Differ. v. 19, n. 1, p. 87-95, 2012.

FIALHO, M. C. Q. et al. Ultrastructure and immunolocalization of digestive enzymes in the midgut of Podisus nigrispinus (Heteroptera: Pentatomidae). Arthropod Struc. Develop., v. 42, n. 4, p. 277-285, 2013.

FIALHO, M. C. Q. et al. Ultrastructure of the digestive cells in the midgut of the predator Brontocoris tabidus (Heteroptera: Pentatomidae) after different feedings periods on prey and plants. Ann. Entomol. Soc. Am., v. 102, n. 1, p. 119-127, 2009.

GONÇALVES, C. A. P. et al. Effect of nonsteroidal antiinflammatory drugs on apoptosis of epidermal lamellar cells of equines with laminitis. Arq. Bras. Med. Veter. Zootec., v. 65, n. 5, p. $1409-1418,2013$.

KRUCEK, T. et al. Effect of low doses of herbicide paraquat on antioxidant defense in Drosophila. Arch. Ins. Biochem.

Physiol., v. 88, n. 4, p. 235-248, 2015.

LEITE, G. L. D. et al. Effects of atrazine-based herbicide on emergence and sex ratio of Trichogrammatidae

(Hymenoptera). Florida Entomol., v. 98, n. 3, p. 899-902, 2015.

LI, B.; CAREY, M.; WORKMAN, J. L. The role of chromatin during transcription. Cell, v. 128, n. 4, p. 707-719, 2007.

MARTÍNEZ, L. C. et al. Ultrastructure and cytochemistry of salivary glands of the predator Podisus nigrispinus (Hemiptera: Pentatomidae). Protoplasma, v. 251, n. 3, p. 535-543, 2014.

MENEZES, C. W. G. et al. A dieta alimentar da presa Tenebrio molitor (Coleoptera: Tenebrionidae) pode afetar o desenvolvimento do predador Podisus nigrispinus (Heteroptera: Pentatomidae)? Arq. Inst. Biol., v. 8, n. 13, p. 250-256, 2014.

MENEZES, C. W. G. et al. Seletividade de atrazine e nicosulfuron a Podisus nigrispinus (Heteroptera: Pentatomidae). Planta Daninha, v. 30, n. 2, p. 327-334, 2012a.

Planta Daninha, Viçosa-MG, v. 34, n. 1, p. 125-132, 2016 
MENEZES, C. W. G. et al. Reproductive and toxicological impacts of herbicides used in Eucalyptus culture in Brazil on the parasitoid Palmistichus elaeisis (Hymenoptera: Eulophidae). Weed Res., v. 52, p. 520-525, 2012b.

MILES, P. W. The physiological division of labor in the salivary glands of Oncopeltus facilatus (Dall.) (Heteroptera: Lygaeidae). Aust. J. Biol. Sci., v. 20, n. 2, p. 785-797, 1967.

PORTT, L. et al. Anti-apoptosis and cell survival: a review. Biochim. Biophys. Acta (BBA)-Molec. Cell Res., v. 1813, n. 1, p. 238-259, 2011.

REIS, T. C. et al. Avaliação de predador nativo para controle biológico da cochonilha negra da oliveira Saissetia oleae (Oliver) (Hemiptera: Coccidae). Sci. Electr. Arch., v. 6, n. 1, p. 1-6, 2014.

ROST-ROSZKOWSKA, M. M. Ultrastructural changer in the midgut epithelium of Acheta domesticus (Orthoptera: Gryllidae), during degeneration and regeneration. Ann.

Entomol. Soc. Am., v. 101, n. 5, p. 151-158, 2008.

SOTO, A.; OLIVIERA, H. G.; BACCA, T. Morfología e histología del aparato reproductor de Supputius cincticeps (Hemiptera: Heteroptera: Pentatomidae). R. Univer. Ci. Aplic. Amb. Actual. Divulg. Cient., v. 15, n. 1, p. 117-123, 2012.
SWART, C. C.; DEATON, L. E.; ELGENHAUER, B. E. The salivary gland and salivary enzymes of the giant waterbugs (Heteroptera: Belostomatidae). Compar. Biochem. Physiol., v. 145, n. 1, p. 114-122, 2006.

TERRA, W. R.; FERREIRA, C. Biochemistry of digestion. In: GILBERT, L. I.; IATROV, K.; GILL, S. (Ed.). Compreh. Molec. Insect Sci., v. 4, n. 2, p. 171-224, 2005.

TOGNON, R.; NUNES, N. S.; CASTRO, F. A. Apoptosis deregulation in myeloproliferative neoplasms. Einstein, v. 11, n. 4, p. 540-544, 2013.

TORRES, J. B.; OYD, D. W. Zoophytophagy in predatory Hemiptera. Braz. Arch. Biol. Technol., v. 52, n. 5, p. 1199-1208, 2009.

VALOTTO, C. F. et al. Ultrastructural alterations in larvae of Aedes aegypti subject to labdane diterpene isolated from Copaifera reticulata (Leguminosae) and a fraction enriched with tannins of Magonia pubescens (Sapindaceae). R. Soc. Bras. Med. Trop., v. 44, n. 2, p. 194-200, 2011.

ZANUNCIO, J. C. et al. Production and use of Heteroptera predators for the biological control of Eucalyptus pests in Brazil. Ekoloji, v. 23, n. 91, p. 98-104, 2014. 